\title{
Osmanlı İmparatorluğu'nda Devlet Görevlilerinin Sürgün Edilmesi: 19. Yüzyıl Kıbrıs Örneği
}

\author{
The Exile of State Officials in the Ottoman Empire: \\ The Example of $19^{\text {th }}$ Century Cyprus
}

Erdal TAŞBAŞ ${ }^{*}$

Özet: İktidar tarafından bir topluluk ya da bireyin bulunduğu yerden uzaklaştırılması, başka yere zorla göç ettirilmesi anlamına gelen sürgün, değişik amaçlar için kullanılmıştır. Bireyi sürgüne gönderme uygulamasının nedeni, kişiyi cezalandırmak, sürgüne sebep olan olayın geçtiği mahalden uzaklaştırmaktır. Osmanlı İmparatorluğu'nun duraklama ve gerileme dönemlerinde ortaya çıkan sosyo-ekonomik bunalımlara bağlı olarak sürgün cezalarında artış gözlenmiştir. Bu dönemde devlet kurumları arasındaki uyum ve düzenli işleyiş bozulmuş, bu durum devlet görevlilerinin faaliyetlerine de yansımıştır. Devlet görevlilerine dönük şikâyetler üzerine devletin, görevlileri cezalandırma yoluna gittiği, arşiv belgelerinden anlaşılmaktadır ve bu belgelere göre devlet görevlilerine verilen cezalardan birisi de sürgün olmuştur. Bireysel sürgünler için özellikle coğrafi şartları pek elverişli olmayan bölgeler ve adaların seçildiği görülmektedir. Kıbrıs Adası da sürgün cezalarının uygulandığı önemli yerlerden birisi olmuştur. Kıbrıs’a sürgün geleneği adanın Osmanlı topraklarına katıldığı tarihten beri süregelmiştir. 19. yüzyılda da bu gelenek devam etmiş, Kıbrıs sürgünle cezalandırılan devlet görevlilerinin gönderildiği yerlerden birisi olmuştur.

Anahtar Sözcükler: Kıbrıs, sürgün, sürgün nedenleri, devlet görevlileri, cezalandırma

Abstract: Exile, meaning the expelling by the ruling power of an individual or of a whole community to another place, has been employed for various purposes. The aim of exile is to punish the individual and to remove him from the place where the event that led to his exile occurred. A noticeable increase in the number of punishments through exile was witnessed during the period of stagnation and recession in the Ottoman Sultanate as a result of socio-economic depressions. During this period, the harmony between state institutions deteriorated, a factor which also influenced state officials. It is understood from archive documentation that, taking into consideration the complaints made regarding officials, the state chose to punish these officials, and one method of punishment was to send them into exile. It is clear that islands and other places with harsh conditions were chosen for the exile of individuals. Cyprus became an important island for those undergoing exile. Exile to Cyprus became a tradition following its incorporation into Ottoman territory. Cyprus became one of the places where state officials were sent into exile and this tradition continued throughout the $19^{\text {th }}$ century.

Keywords: Cyprus, exile, reasons for exile, state officals, punishment

Sürgün, Osmanlı Ceza Hukukunda tâzir cezalarından birisidir. Kelime anlamı olarak red, tahkir, te'dip (terbiye etme, haddini bildirme), hak üzerine tutuklama gibi anlamları içeren tâzir, İslam Hukukunda tayin edilmiş, şer'i bir cezası olmayan cürümlerden dolayı, padişah veya naibi tarafindan verilen cezaları kapsamaktadır (Pakalın, 1983, 427). Uyarıdan başlayarak idama kadar

\footnotetext{
*Yrd. Doç. Dr., Akdeniz Üniversitesi, Eğitim Fakültesi, Tarih Eğitimi ABD, Antalya, etasbas@akdeniz.edu.tr
} 
giden cezaları içine alan tâzir, sürgünün yanı sıra sopa, kürek, para, kalebentlik vb. cezalardan oluşmaktadır (Daşçığlu, 2007, 36). Bu tâzir cezalarından biri olan sürgün cezası, siyaset cezası olarak da yorumlanmaktadır (Akgündüz, 1999, 3). Bir nevi zorunlu ikamet cezası olan sürgüne gönderilenler, gittikleri yerde rahat hareket edebilme ve oranın sakini gibi yaşayabilme olanaklarına sahiptir. Bununla birlikte sürgüne gönderilenlere verilen en ağır koşullu ceza, kalebentlik cezasıdır (Köksal, 2006, 288). Önemli sürgün yerlerinden biri olan Kıbrıs'a yapılan sürgünlerde de en ağır ceza şekli kalebent ve zindanbentlikti. Adanın şartları açısından bakıldığında en ağır kalebentlik de Magosa Kalesi'ndeydi (Özkul, 2005, 243).

Ağır koşullar içeren ve eski çağlardan beri uygulana gelen sürgüne gönderme Roma İmparatorluğu zamanında ölümle eşdeğer sayıldığı için, eğer bir suçlu idam cezası almışsa bu cezası idama karşılık olarak kabul edilen sürgün cezasına çevrilebiliyordu (Acehan, 2008, 13). Osmanlı Dönemi'nde ise "sürgün" kavramının iki farklı anlamı vardır. Birincisi şenlendirme, boş arazileri tarıma açarak üretimi artırma ve cihat amaçlı olarak demografik dağılımları kontrol altına alma gibi amaçlara dayalı iskandır. İkincisi ise hukuksal karşılığı olan bir ceza yöntemidir. Elbette Osmanlı ceza yöntemi çok çeşitliydi ve sürgün bunlardan sadece birisiydi (Köksal, 2006, 283-284).

Osmanlı Devleti zamanında sürgün yöntemi sosyo-ekonomik nedenlerle uygulanmıştır. Devletin kuruluşundan itibaren yeni fethedilen bölgelerin iskan edilmesi ve 1ssiz arazilerin şenlendirilerek tarıma açılması sıkça başvurulan bir politika olagelmiştir. (Barkan, 1950, 548). Fethedilen bir bölgenin şenlendirilmesi, iskana açılması veya imarı için başka bir bölgeden insanların topluca sürgüne gönderilmesi gerektiğinde devlet, her iki bölgenin kadısına sürgün hükmü gönderirdi. Sürgün gönderecek yerin kadısından, gerekli şartları taşıyanların belirlenmesi ve aileleriyle birlikte gönderilmeleri istenirdi. $\mathrm{Bu}$ iş için merkezden gönderilen memurlar talimatlara uygun şekilde ve kadıların da yardımıyla sürülecek aileleri sevk ederlerdi. Gidenleri sürgün yerinde yüksek rütbeli memurlar teslim alır ve imzalı kayıtları içeren defterleri merkeze iletirlerdi. Bu şekilde nüfus ve yeni iskan sahalarının da kontrolü sağlanırdı. Ayrıca sürgüne gönderilecek olanlara birer de kefil bulunurdu. Eğer sürgün edilecek kişi firar ederse yerine kefilleri gönderilebilirdi (Daşçığlu, 2007, 176). Bir bölgeden sürgün edileceklerin mevcudu köy veya kasabanın büyüklüğüne göre, on haneden bir ya da iki hane hesabına göre belirlenmekteydi (Barkan, 1950, 546).

Yeni fethettiği topraklara sürgün yoluyla nüfus ihraç eden Osmanlı Devleti'nin kuruluş ve genişleme dönemlerinde fetih politikası gereğince, ele geçirilen yerlerde kalıcı olarak egemenlik sağlaması gerekiyordu. Bu nedenle, fethedilen yeni topraklara, devlet siyasetine uygun olarak nüfus nakilleri yapılmıştır (Yılmaz, 1999, 587; Babuş, 2006, 27; İpek, 2006, 327). Bu politikalar çerçevesinde, fethedilen toprakları şenlendirme amacıyla, oralara kendi halkını iskan etme gibi bir politikayı Osmanlı Devleti kuruluşundan beri uygulamıştır. Bu amaçla çıkarılan sürgün emirlerinden birisi de Kıbrıs içindir. Kıbrıs Adası fethedildiğinde oranın şenlendirilmesi ve iskanı için 1571 'de bir sürgün emri çıkarılmıştır. Ancak ada, zamanla sürgün cezası alanların infaz için gönderildiği bir yer olarak da kullanılmaya başlamıştır.

Kıbrıs'ın yanı sıra, Osmanlı Devleti zamanında sürgünle cezalandırılanların en çok gönderildiği bölgeler Adana, Akka, Ankara, Antalya, Ayas, Ayranoz, Bağdat, Bilecik, Bingazi, Bolu, Bozcaada, Bursa, Çankırı, Çorum, Dazkırı (Afyon), Dimetoka, Diyarbakır, Edirne, Ermenek, Fizan, Halep, İstanköy, İzmir, İznik, Karahisar, Kars, Kıbrıs, Kudüs, Kütahya, Limni, Malta, Manisa, Maraş, Midilli, Mudanya, Rodos, Sakız, Samsun, Seddülbahir, Sinop, Sivas, Sultaniye, Suriye, Tekfurdağı, Tırhala, Tırnova, Tire, Trablusgarp, Trabzon ve Yemen'dir (Acehan, 2008, 27).

Anadolu sahillerinden 70 km. uzaklıkta ve 9.251 kilometrekare alana sahip olan Kıbrıs Adası, Akdeniz'in (Sicilya ve Sardinya'dan sonra) üçüncü büyük adasıdır. Toroslar'ın kuşattığı Çukurova ve Amanosların kuşattığı Hatay bölgesi arasında bir ada olan Kıbrıs, konum olarak bu bölgelerle 
bir bütünlük arz eder (Yıldırım, \& Atik, 2010, 3). Akdeniz'de büyük medeniyetlere ev sahipliği yapmış iki adadan (Girit ve Kıbrıs) birisi olan Kıbrıs, Anadolu, Asya, Afrika ve denizci Avrupa kavimleri arasındaki ilişkilerde eski çağlardan beri önemli bir rol oynamıştır (Gürsoy, 1971, 41).

Kıbrıs Adası, 1571 yılında Türk hakimiyetine girmeden önce Venediklilerin elinde bulunduğu için burada Katolik dini etkiliydi. Katoliklerin büyük baskılarına maruz kalan Ortodokslar, Osmanlı Devleti'nin adayı fethetmesini memnuniyetle karşılamışlardı (Manisalı, 2003, 15). Akdeniz'de bir korsan adası olarak kullanılan Kıbrıs, Osmanlı Devleti tarafindan fethedildiğinde hukuk, kültür ve ekonomi yönünden daha özgür ve düzenli bir yapıya kavuşmuştu. Osmanlı Devleti, kendi ekonomik işleyişinde önemli bir yere sahip olan vakıflar sistemini, burada da faaliyete geçirmişti. Bu vakıf sistemi bazı aksaklıklar dışında günümüze kadar uygulama alanı bulmuştur. Ayrıca adada Osmanlı Döneminde yapılan suyolları, han, köprü, cami ve çeşmeler gibi önemli işlevleri olan mimari yapılanmalar, adadaki sosyo-ekonomik faaliyetleri geliştirmiştir (Manisalı, 2003, 16). Bu mimari yapılanmaların yanı sıra yeni iskana açılan ve boş bulunan topraklarda yapılan zaviyeler de o coğrafyanın şenlendirilmesi ve imarında büyük rol oynamışlardır (Barkan, 2002, 145).

Kıbrıs'ın fethinden sonra burada takip edilen iskan politikasının daha önce fethedilmiş olan Rodos Adası'nda uygulanan iskan ve sürgün politikasının devamı olduğu görülmektedir (Erdönmez, 2007, 68). Fetihle birlikte adanın gelir kaynakları ve nüfusunun kayıtları yapılarak, gelirlerin bir kısmı padişaha has olarak ayrılırken bir kısmı da fetihte görev alan askerlere dağıtılmıştır. Bu ilk işlemlerden sonra Lefkoşa merkezli Kıbrıs Beylerbeyliği kurulmuştur. Bunların yanı sıra adaya sancakbeyi, defterdar, müftü, kadı ve yeniçeri ağası tayinleri yapılmıştır (Erdoğru, 1993, 45-46; Arslan, 2001, 338). Yönetici sınıftan olan bu görevliler adaya yerleştirilmiş olan ilk Türklerdi. 1572'de Lefkoşa, Girne, Mağosa, Baf ve Limasol kalelerinde sayıları 2.779'u bulan gönüllüler, kale muhafizları, azebler ve topçular ile 1.000 kadar da yeniçeri bulunuyordu. Bu görevlilerin bazılarına aileleriyle oturma izni, evlenmek isteyenlere de Anadolu'dan kız alma izni verilmişti. Ancak bütün bu teşvikler Kıbrıs'ın şenlendirilmesi için yeterli olmamış ve buraya sürgün yoluyla yapılacak bir iskan, zorunlu hale gelmişti (Dündar, 1999, 634).

1572 yılında yapılan nüfus tespit çalışmalarında Mesarye ve Mazato bölgelerindeki 76 köyde hiç kimsenin yaşamadığı görülmüştür (Yıldırım, \& Atik, 2010, 17). Fethi tamamlanan Kıbrıs'ın, hem Osmanlı toprağı sıfatını kazanması hem de adanın savunmasını kolaylaştırması amacıyla buraya Müslüman Osmanlı tebaasının yerleştirilmesi gerekliydi. Bu nedenle 21 Eylül 1572'de Sivas, Tokat, Amasya, Karaman ve Zulkadriye kadılıklarına bir sürgün hükmü gönderilmiştir. Bu hükmün birer sureti de İç-il, Bozok, Alaiye ve Teke sancaklarına yazılmıştır. Hükümde, Kıbrıs'ın topraklarının çok bereketli olduğu, adada asayişin tamamlandığı, adaya gelenlerin iki yıl vergilerden muaf tutulacağı ve malları olanların mallarının satılarak parasının kendilerine verilmesi gibi hususlar vardı (Barkan, 1950, 548; Özkul, 2005, 40).

Sürgün hükmü gereği yapılan hesaba göre 5.720 hane Kıbrıs'a nakledilecekti. 1572 yılına ait sayıma göre Kıbrıs Adası'na 225 Aksaray'dan, 262 Beyşehir'den, 202 Seydişehir'den, 145 Endugi'den, 197 Develihisar'dan, 64 Ürgüp'ten, 88 Koçhisar'dan, 172 Niğde'den, 69 Bor'dan, 48 Ilgın'dan, 87 İshaklı'dan ve 130 Akşehir'den olmak üzere toplam 1.689 hane sürgün edilmiştir. Bunların dışında Mut, Silifke, Ermenek, Mamuriye, Karaman, Sivas, Tokat ve Amasya'dan da binlerce kişi Kıbrıs'a sürgün yoluyla göç ettirilmiştir. Bu sürgünlerle adaya yerleştirilen aile say1s1 5.720'yi bulmuştur (Atlay, 1999, 456; Gerçel, 1999, 488; Özkul, 2005, 41). Yine Teke yöresinden 1573 'te başlayan ve sonraki birkaç y1l içinde yoğunluk kazanan sürgünlerde de yüzlerce kişi Kıbrıs'a gönderilmiştir (Karaca, 1999, 651). Gönderilenlerin sürgün yerine ulaşmasında takip edilen belli başlı güzergahlar mevcuttu. Eğer sürgün yerine ulaşmak için deniz yolu kullanılacak ise sürgün sevkleri sahil kentlerinin limanlarından yapılmıştır. Ege adalarına yapılacak sürgünlerde genellikle İstanbul ve Gelibolu limanları kullanılırken, Kıbrıs'a 
Anadolu'dan yapılan sürgünler için Mersin limanı kullanılmaktaydı (Acehan, 2008, 18).

Fethedilen Kıbrıs'ın şenlenmesi ve Türklerin orada iskanı için yapılacak sürgünleri cazip hale getirmek amacıyla adanın çok bereketli boş topraklara sahip olduğu ve bu toprakların bire elli altmış verecek kadar zengin olduğu ileri sürülmüştür (Barkan, 1950, 553). Ayrıca Kıbrıs'ta iskan edileceklere bazı muafiyetler de tanınmıştır. Sürgün hükmünden, gönderilenlerin her türlü vergiden iki sene süreyle muaf tutulacağı anlaşılmaktadır (Barkan, 1950, 548). Ayrıca Kıbrıs Adası'na yapılacak nakliyatlar ücretsiz hale getirilmiş, adada adil muamele görecekleri ve suçları varsa affedileceklerinin garantisi verilmiş̧ir (Daşçıŏlu, 2007, 196). Bunlara ek olarak adaya yerleştirilenlerin farklı meslek guruplarından olması konusunda da titiz davranılmıştır (Halaçoğlu, 2001, 39). Bu şekilde bir uygulamaya gidilmesi, adanın sosyal ve ekonomik anlamda kalkınmasına yardımcı olacağı için Osmanlı iskan siyaseti açısından çok önem arz eden bir uygulama olarak karşımıza çıkmaktadır.

Kıbrıs'a yapılan sürgünler sadece şenlendirme amaçlı olmamıştır. Çeşitli nedenlerle cezaya çarptırılan insanların cezalarını çekecekleri yerlerden biri de Kıbrıs Adası olmuştur. Aşiretlerin yerleşik hayat süren ahaliye verdikleri zararlar nedeniyle XVII. yüzy1lda adaya sürüldükleri bilinmektedir. Bunların dışında adaya yapılan suçlu sürgünü aralıklarla da olsa sürekli devam etmiştir (Özkul, 2005, 238). Ancak zararlı davranışları nedeniyle sürgün yeri olarak seçilen Rakka ve Kıbrıs Adası'na gönderilen bu aşiretlerin bir kısmı buralardan kaçarak eskisi gibi eşkıyalık hareketlerine devam etmişlerdir (Halaçoğlu, 2006, 38-40).

Kıbrıs'ın şenlendirilmesine yönelik çalışmalarda Osmanlı Devleti'nin oldukça titiz hareket etmiş olmasına rağmen Kıbrıs Adası'nın sakinleri gerek yaşam koşullarının zorluğu gerekse bazı yıllarda yaşanan salgınlar, kuraklık, kıtlık ve deprem gibi olumsuzluklar yüzünden, buradan kaçmak suretiyle adayı terk ettikleri görülmüştür. Bu durum adadan sağlanan gelirleri düşürdüğü gibi ada nüfusunun da azalmasına neden olmaktadır (Özkul, 2005, 242).

Ancak Kıbrıs Adası'nın demografik dağılımına XIX. yüzyılın çeşitli dönemlerinde etki eden başka bir faktör daha vardı. Bu da Osmanlı topraklarına sığınan ve değişik bölgelere gönderilen muhacirlerin iskanıydı. Osmanlı Devleti'nin topraklarının küçülmesine bağlı olarak kaybedilen topraklardan XIX. yüzyılda milyonlarca muhacir gelmişti ve bu muhacirler boş veya uygun olan arazilerde iskan edilmişti. XIX. yüzyılda Kırım ve Kafkasya'dan gelen muhacirlerin bir kısmı da Kıbrıs'ta iskan edilmeye çalışılmıştır. Ancak Kıbrıs'a yönelik bu girişim her hangi bir siyasi ya da stratejik nedenle değil, insani amaçlarla yapılmıştır (Erdönmez, 2007, 72). Özellikle 18571866 yılları arasında Osmanlı topraklarına göç eden bir buçuk milyon Çerkes'ten 10.000 kadarı, iskan için Kıbrıs'a gönderilmişlerdir (Avagyan, 2004, 66). Öte yandan XIX. yüzyılın son çeyreğinde Osmanlı topraklarına yapılan Yahudi göçünde önemli bir artış yaşanmıştı. Yüzyılın son on yılı içinde Rus baskıları nedeniyle Osmanlı Devleti'ne sığınan binlerce Yahudi aileden bir kısmı da iskan için Kıbrıs'a sevk edilmişti (Buzpınar, 2002, 78).

\section{Devlet Görevlilerinin Sürgün Edilme Nedenleri}

Bir yerden uzaklaştırılma, birey ya da bir topluluğun zorla göç ettirilmesi ve bir yerde iskana tâbi tutulma cezası olan sürgünün iki temel nedeni vardır; birincisi bireyin cezalandırılarak bulunduğu yerden alınıp başka bir yerde zorunlu olarak iskan ettirilmesidir. İkincisi ise toplumu etkileyecek sosyo-ekonomik politikaların gereği olarak toplu sürgün edilmedir (Daşçığlu, 2007, 47).

Çok geniş topraklara ve doğal olarak da büyük bir yönetici ve memur zümresine sahip olan Osmanlı Devleti'nin askeri, sosyal ve ekonomik kurumlarında işleyiş ve yapılanmasında, XVI. yüzyıldan itibaren bozulmalar ortaya çıkmıştır. $\mathrm{Bu}$ yapılanmadaki bozulmalar, devlet görevlilerinin tutum ve davranışlarına da yansıyacaktır. Suç oluşturan davranışları nedeniyle halk tarafından şikâyet edilen memurları cezalandırma yoluna giden devletin başvurduğu cezalandırma 
yöntemlerinden biri de onları sürgüne göndermek olmuştur.

Devlet görevlileri arasındaki anlaşmazlıklar, çekememezlik, nefret ve düşmanlıklar, sonu sürgünle biten problemlere yol açmaktaydı (Daşçıŏlu, 2007, 125-126). Ayrıca devlet görevlilerinin işlerini gerektiği gibi yapmamaları, yetersiz kalmaları gibi durumlarda da görevden alınarak sürgüne gönderildikleri görülmektedir. Bununla birlikte devlet hakkında olumsuz düşüncelerde bulunan ve bu düşüncelerini eleştiri yoluyla yaymaya çalışanlar da sürgün edilmişlerdir (Daşçığlu, 2007, 128-129). Düzene aykırı davranışlar, görevi kötüye kullanmak, halka baskı ve zulüm uygulamak, cürüm işlemek, iftira atmak, yalancı şahitlik yapmak, fesatçı davranış ve eylemlerde bulunmak, fuhuş yapmak ya da yaptırmak, İslam dini açısından haram sayılan içki vb. maddeleri kullanmak, imana sövmek, başkalarının kadınlarına saldırmak, cinayet işlemek, hırsızlık yapmak, eşkıyalık ve şer'î hükümlere riayet etmemek gibi suçlar, devlet görevlilerinin sürgüne gönderilmesine yol açan nedenler arasında en sık karşılaşılanlarıdır.

Sürgünle sonlanan suçlardan olan devletin işleyişine zarar verebilecek, düzenini bozucu davranışlarından dolayı İşkodra'da görev yapan İkinci Alay Emini İsmail Bey dava edilmiş ve İşkodra'daki Divan-1 harpte görülen muhakeme tarafından sürgünle cezalandırılmıştır. Dar-1 Şuray1 Askeriye'ye gönderilen karar incelenmiş ve askerlik görevinden çıkarılarak Eylül 1839'da Kıbrıs'a sürülmüştür. Ancak bu mahkum daha sonra affedilerek salıverilmiştir (BOA., C.AS., 862/36917).

Devlet görevlilerinin sürgünle cezalandırılmasına neden olan suçların en sık görülenlerinden birisi de görevi kötüye kullanma ile halka baskı ve zulüm uygulamaktır. Yetkililerin hukuka aykırı bu tür eylemleri halk tarafından bölgenin kadısına ya da doğrudan saraya şikâyet edilebilmekteydi. Osmanlı halkının bu haklarına rağmen yine de yetkililerin görevlerini kötüye kullanma, baskı ve zulüm gibi davranışlarının önüne geçilemiyordu. Örneğin İstanköy Adası gümrük memuru Hüseyin Efendi'nin üzerine büyük miktarda zimmet geçirdiği ortaya çıkmıştı. Üzerine geçirdiklerine devlet adına el konulduktan sonra Hüseyin Efendi, 1865 yılında tutuklanarak sürgüne gönderilmek üzere İzmir valiliğine teslim edilmiştir. Bu şahsın sürgün cezasını çekeceği yer olarak da Kıbrıs Adası belirlenmişti (BOA., A.MKT.MHM., 330/80; BOA., İ.MVL., 584/26280).

Yine Yeniçeri Ocă̆ı'nda başyazıcı iken daha sonra İstanbul Ağalı̆̆ı'na getirilmiş olan Mehmed Efendi görevi kötüye kullanma suçu teşkil eden uygulamaları nedeniyle Kıbrıs'a sürülmüştü. Ancak Mehmed Efendi bir süre sonra affedilmiştir (BOA., HAT., 196/ 9788). Devlet düzenini bozucu eylemlerinden dolayı sürgün edilenler arasında, görevi kötüye kullananların dışında bir de zalim uygulamalara imza atan devlet görevlileri vardır. Örneğin halka baskı ve zulüm niteliğinde davranışlar sergilediği görülen Niğde sancağ 1 alaybeyi, Eşkinci Ocağı'na bağl1 askerler ve Niğde ahalisinin şikâyetleri neticesinde, görevinden azledilmiş ve 1818 yılında Kıbrıs'ın Lefkoşa Kalesi'ne sürgüne gönderilmiştir (BOA., C.DH., 236/11768).

Devlet görevlilerinin sürgüne gönderilme nedenleri arasında cürüm işlemek, küçük kabahat sayılacak eylemlerde bulunmak gibi suçlar da sık görülen suçlardandır. Bu suçların ceza süreleri de değişiklik göstermektedir. Örneğin cürüm nedeniyle Ezine Kazası'nın eski müdürü Hasan Efendi ve suç ortağı Lapsekili Ali Molla, 1854 yılında bir yıl için (BOA., A.MKT.UM., 192/72); Adana Eyaleti'nin Toros Sancağı meclis azası olan Mısırlızade Ali Efendi, 1855 yılında süresiz olarak (BOA., A.MKT.UM., 219/31); 1860 yılında ise posta müdürü Çerkes İsmail Paşa üç sene sürgün cezasına çarptırılmış ve Kıbrıs'a gönderilmişlerdir (BOA., A.MKT.NZD., 334/86; BOA., A.MKT.UM., 406/91). Ayrıca Tophane Ruznamçe kâtiplerinden Arif Bey, aynı suçtan Kıbrıs Adası'na sürgün edilmişti. Ancak 20 Temmuz 1860 tarihli belgeye göre, Arif Bey cezasını dolduramadan sürgün cezasını çektiği Kıbrıs'ta hayatını kaybetmiştir (BOA., İ.MVL., 434/19139).

Sürgündeyken yaşamını yitiren devlet görevlilerinin kendilerine tahsis edilen maaşları da aileleri tarafindan talep edilebilmekteydi. Tophane Ruznamçe kâtiplerinden Arif Bey'in Kıbrıs'ta sürgün hayatı yaşarken ölmesi varislerini harekete geçirmiş, merhuma tahsis edilmiş olan 150 
kuruş maaşı varislerince talep edilmiştir. Zor durumda olduklarını ileri sürerek merhumun maaşının kendilerine bağlanması için başvuru yapmışlardır. Ser-askerlikten hükümete yazılan yazıya göre başvuruları olumlu karşılanmış ve Arif Bey'in maaşı varislerine tahsis edilmiştir (BOA., İ.MVL., 434/19139).

Cürüm nedeniyle cezalandırılanların sürgün sürelerinin belli olmadığı durumlar da söz konusudur. Örneğin, Diyarbakır Eyaleti'ne bağlı Mihriban Kazası nahiyeleri subaşılarından on kişi cürüm sayılabilecek hareketlerinden dolayı Kıbrıs Adası'na sürgün edilmişti. Bunların ne kadar süreyle sürgün cezasına çarptırıldıkları bilinmemektedir. Ancak hepsi de 1848 yılında affedilmişlerdir (BOA., C.ZB., 89/4420).

Sürgün suçlarından birisi de şer'̂̂ hükümlere aykırı davranışlardır. Bu suçu işleyenlerin dini kurumlarda görev yapması bu tür davaların önemini artırmaktadır. Böyle durumlarda verilen cezalar Osmanlı kurumsal işleyişi bakımından ayrı bir önem arz etmektedir. Örneğin İstanbul'daki Sultan Mehmed Camisi'nin kayyumu Konyalı Ali isimli yetkilinin şeriata aykırı ve kabul edilemez hareketlere cüret ettiği bildirilmiştir. Yapılan soruşturma sonucu bu şahıs 1821'de Kıbrıs Adası'nın Magosa şehrine sürülmüştür. Bu suçluya sürgün cezalarının en ağırlarından olan kalebentlik cezası verilmiştir (BOA., C.ZB., 29/1404). Bunların dışında devlet görevlilerinin sürgünle sonuçlanan iftira atmak, fesatçı davranış ve eylemlerde bulunmak gibi suçlanı da mevcuttur. 1862 yılında Cidde eski kaymakamı Hacı İbrahim Ağa iftira etme suçu nedeniyle Kıbrıs'a sürgün edilmişti (BOA., A.MKT.UM., 571/71).

\section{Devlet Görevlilerinin Sürgünleri}

Sürgün cezasının uygulanması hususu birçok hukuki işlem gerektirmektedir. Suçlu aleyhinde yapılan şikâyet ister doğrudan saraya ister mahallin kadısına yapılsın, suçun işlendiği ve suçlunun bulunduğu yerin ilgili mercilerine haber verilir ve burada konunun soruşturulması istenirdi. Suçlanan kişinin devlet görevlisi olması halinde onun mevki ve sınıfına göre soruşturma yapılırdı (Köksal, 2006, 295). Yapılan sorgulama neticesinde sürgün cezası gerekli görülürse bu durum sadarete sunulmakta ve buradan da padişaha arz edilmektedir (Köksal, 2006, 296). Sürgün cezasının infaz edilmesi hususunda son kararı padişah verirdi. Eğer padişah sürgün kararını onaylarsa bir sürgün fermanı hazırlanır ve suçluya kararı bildirmek ve onu sürgün yerine götürmekle görevlendirilen yetkiliye bu karar teslim edilirdi. Bu kararı içeren ferman, genellikle sürgüne gönderilecek kişinin bulunduğu yerin mülki idarecisine ve sürüleceği yerin kadısına veya naibine yazılırdı (Köksal, 2006, 296).

Suçlunun sürgün yerine götürülmesi aşaması devletin görevi olduğu için bütün bu işlerin masrafını da devlet üstlenmekteydi. Sürgün yerinin uzaklığı ya da suçlunun statüsüne bağl1 olarak bu masraflar değişiklik göstermektedir. Suçluyu güvenli bir biçimde sürgün yerine götürecek olan görevlilerin erzak ve barınma masrafları, kara ya da deniz vasıtaları için ödenecek ücretler bu husustaki belli başlı masraflardır (Köksal, 2006, 298).

Sürgüne giden kişinin sürüldüğü yere götürülmesi, sürgündeki kişinin yeniden sürgün yemesi ya da sürüldügü yerin değişmesi gibi durumlarda çavuşlar görev yapmaktaydı. Sürgün işlerinde görevlendirilen ve sürgün infazında önemli bir yeri olan çavuşların da zaman zaman yolsuzluklar nedeniyle sürgün edildikleri görülmüştür (Daşçığlu, 2007, 135). Cezalıyı sürgün yerine götüren görevli, burada fermanı okumak suretiyle halka duyurur, fermanın bir örneğini kadı siciline kaydettirirdi. Arkasından suçlunun sürgün yerine getirilmesi görevini ifa ettiğine ilişkin belge olan ilamı alıp merkeze geri dönerdi. Bu ilam hem işin görüldüğünün kanıtı hem de infazın başlangıç tarihi demekti. Bundan sonra sürgün edilenin yeni ikametgâhındaki bütün yaşamı, oranın kadısının kontrolü altındadır (Köksal, 2006, 298).

Çavuşlar gözetiminde sürgün yerine gönderilen suçluların, hem işlemlerinin aksamaması hem de yolculuk güvenliğinin sağlanması için durum sürgün yeri kadısı ile gidiş güzergahındaki 
güvenlik birimleri, kadı ve naiplere yazıyla önceden bildirilirdi. Rodos'ta Azeban (donanma hizmetleri ile görevli asker) Ağası Mustafa Ağa işlediği suçtan dolayı sürgün cezasına çarptırılmış, Tersane-i Amire tarafından bir çavuşun gözetiminde Kıbrıs Adası'na gönderilmiştir. Bu sürgün cezasının gerektiği gibi infaz edilebilmesi amacıyla Rodos ve Kıbrıs kadılarına hitaben bir yazı yazılmıştır (BOA., HAT., 266/15417). Yine suçlu bulunan devlet görevlilerinden biri olan eski Eflak Kapı Kethüdası Kıbrıs'a sürgünle cezalandırılmıştı. Cezanın infazı ve şahsın sürgün yerine gönderilmesi görevi Divan-1 Hümayun çavuşbaşılarından Mehmed Emin Bey'e verilmiş ve gemiyle Magosa'ya gönderilmişlerdi (BOA., C.MTZ., 14/665).

Sürgüne gidişte yol güvenliğinin sağlanması sürgünün gerçekleşmesinde önemli hususlardan biriydi. Suç nedeniyle sürgüne gönderilmesi kararlaştırılan Nur-i Osmanî Camisi kâtibi Süleyman Bey, görevlendirilen bir çavuşla Kıbrıs Adası'na sürgüne gönderilmişti. Yolculuk süresince yanında bulundurması amacıyla çavuşa verilen bir fermanda, Üsküdar'dan Kıbrıs'a kadar geçecekleri yol üzerindeki kadılar, naipleri ve zabitanlara, kendi bölgelerine bu suçlu ve çavuşun uğramaları durumunda firar yaşanmaması için gerekli önlemleri almaları emredilmiş̧i. Herhangi bir firar durumuna karşı muhafazasına dikkat etmeleri, geçilecek sıkıntılı yerler için gerekirse yanlarına görevli vermeleri ve bu konuya özen göstermeleri istenmiştir (BOA., C.ZB., 67/3347).

Hem yolculuk boyunca hem de sürgün yerindeki güvenlik önlemlerine ve gösterilen özene rağmen zaman zaman sürgün cezalısının bulunduğu yerden firar ettiği durumlar da yaşanmıştır. Koşulları ağır olan sürgün bölgelerinden biri olan Kıbrıs Adası da firar olaylarının yaşandığı yerlerdendir. Örneğin posta müdürü Çerkez İsmail Paşa cürüm işleme nedeniyle üç sene sürgün cezasına çarptırılmıştı. Sürgün cezası için Kıbrıs Adası'na gönderilmiş olan bu şahsın 23 Kasım 1860 tarihinde Lefkoşa'da bulunduğu konaktan gece saat üç sıralarında dışarı çıktığı ihbar edilmişti. Konaktan çıkması firar edebileceği şüphesi uyandırdığı için bütün güvenlik güçleri kasabaya dağılmış, kale muhafazasıyla görevli askerlere de haber verilerek mahkûm sabaha kadar aranmışsa da bulunamamıştır. Firarinin kendini kale duvarlarından dışarı atıp kaçtığı anlaşılmış ve tahkikat başlatılmıştır. Fransız konsolos vekili Mösyö Lafön'ün tercümanı Kıbrıslı İlya'nın da saat üç sıralarında yaya olarak Lefkoşa kale kapısından dışarı çıktığı bildirilmiştir. Firarinin Mösyö Lafön ve tercümanı İlya ile yakın ilişkisi olduğu bilindiği için tercüman İlya ve İsmail Paşa'nın Tuzla İskelesi'ne kaçtıkları düşünülmüş ve durum Tuzla Kazası müdürüne bildirilmiștir. Tercüman İlya'nın sabaha karşı iskeleye gelerek Sicilya devleti tebaasından Balıkçı Tebraki isimli birisinin evine, yanında bir arkadaşıyla gittiği görülmüştür. Oradan bir sandalla gemiye geçmişler ve adadan ayrılmışlardır. Durum Beyrut ve İzmir valilerine bildirilmişse de kaçmalarına engel olunamamıştır (BOA., A.MKT.NZD., 334/86).

Sürgün yeri suçun niteliğine göre değişmektedir. Gerçi sürülenler devlet görevlisi ise suçlunun mevkii, statüsü ve benzeri durumlara göre sürgün yeri değişebiliyordu. Sürgüne gönderilenlerin kaçabilmeleri ihtimalini azaltmak ve onları kolayca zabt etmek için genellikle adalar ya da sahil kentleri tercih ediliyordu. Bu özelliğe sahip olan yerlerden biri olan Kıbrıs Adası da bir mahrumiyet bölgesi olarak görüldüğü için cezalandırma amaçlı sürgünlerin gönderileceği bölgelerdendir (Halaçoğlu, 2006, 110). Zaman zaman merkezden çok uzak mahaller de sürgün yeri olarak seçilebiliyordu. Bu bölgeler genellikler Kuzey Afrika ve Arap coğrafyasında bulunmaktaydı. Ancak suçu hafif görülen devlet görevlileri, özellikle devletin yüksek makamlarında görev yapmış olanlar ve ilmiye sınıfı mensupları, merkeze yakın sancaklara ya da gelişmiş kentlere sürgün olarak gönderilmişlerdir. Ancak sonradan sürgün yerlerinde değişiklik de yapılabilmekteydi (Köksal, 2006, 288). Diğer taraftan devlet görevlilerinin sürgünleriyle boşalan kadrolara yeni birisinin atanması işlerin aksamaması için önem arz etmektedir.

Sadece düşük kademeli değil yüksek mevkilerde görev yapan devlet görevlileri de zaman zaman sürgüne gönderilmiştir (Daşçığlu, 2007, 123). XIX. yüzyıldan önceki dönemlerde de 
çeşitli devlet görevlilerinin Kıbrıs'a sürgün edildikleri bilinmektedir. Bunlar arasında kadılar, müftüler, Divan-1 Hümayun çavuşları, şehreminiler, muhzırbaşı ve sakkakbaşı (şer'i mahkemelerde ilam, hüccet ve berat gibi yazıları kaleme alan kâtip) gibi görevliler sayılabilir (Özkul, $2005,239)$. Tabii sürgüne gönderilen bir devlet görevlisinin suçundan dolayı aldığ1 tek ceza sürgün olmuyordu. Suçlu mutlaka görevinden azlediliyordu. Unvanları da elinden alınan devlet görevlisinin maaşı kesilmekte ve suçunun niteliğine bağlı olarak mallarının bir kısmına ya da tamamına el konulmaktaydı (Köksal, 2006, 288). Örneğin üzerine büyük miktarda zimmet geçirdiği ortaya çıkan İstanköy Adası gümrük memuru Hüseyin Efendi'nin mallarına, devlet adına el konulduktan sonra tutuklanarak Kıbrıs'a sürgüne gönderilmek üzere İzmir Valiliği’ne teslim edilmişti (BOA., A.MKT.MHM., 330/80). Ancak Hüseyin Efendi'nin zimmetinde bulunan on sekiz bin altı yüz on bir kuruş on yedi para tahsil edilememişti. Bu durumda zimmetin borçlu ve kefilden hangisinin ileride kazanç elde ederse ondan, tahsil edilmesine karar verilmiştir (BOA., İ.MVL., 584/26280).

Sürgünle cezalandırılan kimsenin mallarına el konulacaksa bu işlemin yapılması için saraydan güvenilir birisi derhal suçlunun mallarının bulunduğu bölgeye gönderilirdi. Suçlunun mallarını büyük bir titizlikle tetkik eden bu müsadere memuru, söz konusu mallara devlet adına el koyarak onları bir deftere kaydederlerdi. Suçlunun önceden tedbir alması ya da kaçması gibi gelişmelere mahal vermemek için bu müsadere işlemi büyük bir hız ve gizlilik içinde yapılırdı (Köksal, 2006, 297).

Osmanlı'da sürgüne gönderme şeklindeki cezaların süresi kısadır. Çünkü amaç, suçlunun ıslah edilmesi, başkalarının bunu ibret alması ve caydırıcılıktır. Sürgün cezalarına uğrayanların ekserisi değişik sınıflardan devlet görevlileri olmuştur. Devletin kendi çalışanlarını yeniden kazanmak istemesi de sürgün süresinin kısa tutulmasının bir sebebi olabilir (Köksal, 2006, 300). Ancak sürgün kısa süreliğine de yapılsa Osmanlı ceza hukukunda sürgüne gönderilenlerin cezalarının süresi genellikle net değildir. Ancak bu tür cezalandırmaların uzun yıllar sürmediği bir ya da iki sene sonra afla sona erdiği görülmektedir.

Oldukça çeşitli nedenlere dayalı olarak verilen af kararları cezayı veren makama aittir. Sürgüne gönderilmede son karar mercii padişahın kendisi olduğu gibi, sürgüne gönderileni affetmek yetkisi de padişaha aittir. Cezaların affedilmesi iki şekilde olmaktadır. Birincisi; çeşitli sebeplerle zaman zaman çıkarılan genel aflardır. Genel af, özellikle padişahın tahta çıkması ve tahta çıkışının yıldönümlerinde ya da çeşitli sevindirici gelişmeler, savaşlar ve iç karışıklıklar gibi sosyal, ekonomik ve siyasi kaygılarla çıkarılmıştır. İkincisi ise özel aftır. Özel af, cezanın hafifletilmesi ve tamamen ortadan kaldırılması olarak iki şekilde zuhur eder. Cezasının hafifletilmesi; sürgün yerinin değiştirilmesi, eski unvan ve mevkisini kullanmaması şartıyla memleketine dönüp burada ikamet etmesine izin verilmesi ve bir şeye karışmamak koşuluyla serbest dolaşım hakkını kazanması gibi durumları ifade eder. Sürgün yerinin değiştirilmesi için suçlunun sürüldüğü yerde cezasının bir kısmını tamamlaması şarttır. Cezanın tamamen ortadan kaldırılmasıyla neticelenecek özel af şekli ise suçluyu sürgüne gönderilmesinden önceki statüsüne kavuşturmaktadır (Köksal, 2006, 301-302). Bu şekilde affedilmek devlet görevlisi olan sürgünler için yeniden görevine dönebileceği anlamına gelmektedir.

Sürgün cezası affedilip eski görevlerine yerleştirilenlerin dışında bir de eski görevleri yerine başka bir görev verilen sürgünler vardır. Örneğin Yeniçeri Ocağı'nda başyazıcılıktan sonra İstanbul Ağalığı'na getirilen Mehmed Efendi, görevini kötüye kullanma suçu teşkil eden uygulamaları nedeniyle Kıbrıs'a sürülmüş, ancak bir süre sonra affedilmişti. Mehmed Efendi'nin herhangi bir güvencesi olmadığı için ocağın eski sekbanbaşı Ömer Ağa ve yeni sekban ağası, kendisine hocalık rütbesinin geri verilmesini ısrarla rica etmişlerdir. Bu ricalar dikkate alınmış ancak Mehmed Efendi'nin ocaktaki eski görevine değil de Sohum tarafına nüzul emini (sefere giden orduların konaklayacağı yerleri belirlemek ve konakladıkları zaman yiyecek ve içecekle- 
rini temin etmekle görevli memurdur. Konakçıbaşı da denilen bu görevli, yaptığı işlerin giderlerini halktan alınan avarız ve nüzul denilen vergilerden karşılardı (Pakalın, 1983, 710.)) olarak gönderilmesine karar verilmiştir (BOA., HAT., 196/ 9788).

Elbette her başvuru afla sonuçlanmıyordu. Cürüm nedeniyle bir sene sürgün cezasına çarptırılan ve cezayı çekmesi için Kıbrıs'a gönderilenlerden Lapsekili Ali Molla'nın, Ezine Kazası'nda bulunan ailesi ve ihtiyar annesi kefalette bulunarak cezalının affını istemişlerdir. Ali Molla'nın arkadaşı Ezine Kazası'nın eski müdürü Hasan Efendi'nin de 1slah olduğu ve cezalarının da yedi ayını doldurdukları gerekçesiyle affedilmeleri istenmiştir. Ancak merkezden Biga Mutasarrıflı̆̆ı'na gönderilen 25 Nisan 1855 tarihli yazıda bu isteklerine olumsuz cevap verilmiştir. (BOA., A.MKT.UM 192/72). Af işlemi uygulanmadığı bu gibi durumlarda verilmiş olan sürgün cezası, süresinin dolması durumunda sona ermektedir. Bu nedenle Lapsekili Ali Molla ve suç ortağı Ezine Kazası'nın eski müdürü Hasan Efendi, 1854 yılında bir yıl için gönderildiği Kıbrıs'tan ancak cezalarını doldurduktan sonra 1855 Kasımında salıverilmişlerdir (BOA., A.MKT.UM., 214/75). Yine uygunsuz davranışları nedeniyle rütbesi elinden alınarak Kıbrıs'a sürgün edilen Binbaşı Kâzım Bey de sürgün cezasını adada doldurarak sona erdirmiştir (BOA., A.MKT.MHM., 251/86).

Bazı durumlarda sürgüne gönderilecek kişinin hasta veya yaşlı olması cezanın infaz edilmemesi için gerekçe oluşturabilmekteydi. Ayrıca sürgün edilecek kişinin ailesinin durumu da dikkate alınırdı. Bazen kişinin bütün ailesi de suçlu olduğu için topluca sürgün edilirlerdi. Suçlunun sürgün edilmesi, ailesinin yaşantısını çok kötü etkileyecekse, ailesinin perişan olmaması için onlar da suçluyla birlikte sürgüne gönderilirlerdi (Özkul, 2005, 240; Daşçığlu, 2007, 133). Sürgün cezalarının hafifletilmesi ve cezanın ortadan kaldırılması gibi iki şekilde zuhur eden özel aflar ceza süresi dolmadan sürgünden kurtulmanın tek yoludur. Özel afların uygulanmasına vesile olan durumların başında sürgüne gönderilen kişinin ailesinin bu olaydan dolay1 perişan duruma düşmesi, sürgüne gönderilenin hastalanması veya 1slah olduğuna inanılması gelmektedir. XIX. yüzyılda sürgün cezasına çarptırılmış ve bu cezayı çekmek için Kıbrıs'a gönderilmiş olan devlet görevlilerinin, yukarıda sayılan durumlara binaen affedildikleri de görülmektedir.

Cürümden dolayı süresiz olarak Kıbrıs Adası'na sürgüne gönderilen Adana Eyaleti'nin Toros Sancağı Meclis Azası Mısırlızade Ali Efendi'nin bakmakla yükümlü oldukları kimseler ve evlatları sefalete düşüp perişan olmuşlardı. Ali Efendi, sürgüne gönderileli beş aydan fazla zaman geçtiği için merhamet gösterilip affedilmesi istenmiştir. Cezalının durumu incelenmiş ve suçu tahrik altında işlediğine ve af başvurusunun koşullarına da bakılarak affedilmesine hükmedilmişti. Karar, Kıbrıs Mutasarrıflı̆̆ı'na bildirilerek salıverilmesi sağlanmıştı (BOA., A.MKT.UM., 219/31).

Sürgüne gönderilmiş olan bazı suçluların ıslah oldukları düşüncesiyle cezalarının hafifletilmesi için sürgün yerlerinin değiştirilmesi yoluna gidilmekteydi. Örneğin, Kıbrıs'ın Magosa Kalesi'nde uzun zamandan beri sürgün olarak yaşayan dergâh-1 âli kapucubaşılarından Adanalı Hacı Hasan Ağa'nın, yaşadığı sürgün hayatı boyunca 1slah olduğu ve bu nedenle affedilmesi kararlaştırılmıştı. 1850 Kasımında Kıbrıs'tan hükümete yazılan yazıda şahsın salıverilmesi veya sürgün yerinin Lefkoşa olarak değiştirilmesi konusunda izin istenmiştir. Nihayetinde sürgün yerinin değiştirilmesine karar verilmiştir (BOA., A.MKT.UM., 37/13).

Sürgün yerlerinin değiştirilmesi suçluların istediği yerden ziyade affedici mevkidekilerin istediği yere göre yapılmaktaydı. Kıbrıs'ta sürgünde bulunan Cidde eski kaymakamı Hacı İbrahim Ağa, oranın su ve havasına alışamadığından sürgün yerinin değiştirilerek Trabzon'a veya Samsun'a gönderilmesi için bir dilekçe vermişti. Kıbrıs'tan 2 Mayıs 1862 tarihli yazıyla bildirilen talebi merkezce kabul edilmemiş ve Kıbrıs Mutasarrıflı̆̆ı'ndan mahkûmu adanın havası uygun bir yerine nakletmesi istenmiş̧ir (BOA., A.MKT.UM., 571/71). 
Sürgündeki suçluların affedilmesinde kendisi ve ailesi tarafından gelen talepler dışında kimi zaman da başkalarının taleplerinin dikkate alındığı görülmektedir. Örneğin, kötü muamele ve zalim davranışları nedeniyle Eşkinci Ocağı'na bağlı askerler ve Niğde ahalisinin şikâyetleri neticesinde Niğde Sancağı Alaybeyi görevinden azledilmiş ve Kıbrıs'ın Lefkoşa Kalesi'ne sürgün edilmişti. Ancak bir müddet sonra Niğde halkı alaybeyinin affedilmesini talep etmiştir. Yapılan bu başvuru üzerine alaybeyinin sürgün cezası affedilmiştir (BOA., C.DH 236/11768).

Sürgün aflarına gerekçe olan diğer önemli durumlar, sürgün edilen suçlunun hastalığa yakalanması ve 1slah edildiğinin düşünülmesidir. Yukarıda dergâh-1 âli kapucubaşılarından Adanalı Hacı Hasan Ağa'nın sürgün yeri değişikliğinde, suçlunun 1slah olduğuna inanıldığı için talebinin kabul edildiği belirtilmişti. Buna benzer örnekleri çoğaltmak mümkündür. Mesela, Rumeli eski mutasarrıfı Arif Paşa'nın hazinedarı Mahmut Ağa ile Pirlepe Kazası eski müdürü Mustafa Bey, Kıbrıs'ta sürgün bulunmaktaydılar. Bir buçuk senedir sürgünde olan Mahmut Ağa hastalığa yakalanmış ve perişan bir halde, affedilmek için talepte bulunmuştu. Bu talebi 4 Mart 1852 'de hükümete iletilmiştir. Yapılan yazışmalar ve tetkikler neticesinde Mustafa Bey'in hastalığı nedeniyle affedilmesi kararlaştırılmıştır (BOA., İ.MVL., 235/8212).

Yine Diyarbakır Eyaleti'ne bağlı Mihriban Kazası nahiyeleri subaşılarından on kişi, cürüm sayılabilecek davranış ve uygulamalarından dolayı Kıbrıs Adası'na sürgün edilmişlerdi. Bu hükümlülerin nefislerini islah ettikleri, bu nedenle merhamet gösterilmeyi hak ettikleri ve bundan sonra riza gösterilmeyecek hareketlerde bulunmayacaklarına kefil gösterebilecekleri beyanıyla affedilmelerini istemişlerdir. Yapılan tahkikat ve yazışmalar sonucunda Kıbrıs Meclisi'nden sunulan mazbatalar ile sürgündekilerin 1slah olduklarına dair kefillikler sağlanmıştı. Bu nedenle devlet, çektikleri cezayı yeterli bulmuş ve bu sürgünleri 1848 yılında affetmiştir (BOA., C.ZB., 89/4420).

Devlet görevlilerinin XIX. yüzyıl Osmanlı hukuk ve ceza sistemine dayalı olarak sürgüne gönderme şeklinde cezalandırılmaları sürgün yeri açısından incelendiğinde, Kıbrıs'ın bu bağlamda önemli bir yer tuttuğu görülmektedir. Bazı devlet görevlileri işledikleri çeşitli suçlar nedeniyle diğer dönemlerde olduğu gibi XIX. yüzyılda da Kıbrıs Adası'na sürgün edilmişlerdir. Sürgün edilenler adanın değişik yerlerinde ikamet ettirilmişler ve kalebentlikten zorunlu ikamete kadar çeşitli cezalandırma yöntemleriyle karşı karşıya kalmışlardır. Konuya ilişkin arşiv belgeleri incelendiğinde XIX. yüzyılda Kıbrıs'a yapılan sürgünlerin nedenleri, sürgün bölgesi, sürgün yöntemleri ve prosedürü, sürgündeki yaşam, cezaların niteliği ve süreleri, aflar ve sürgün edilenlerin hukuki hakları gibi hususlarla ilgili çok yönlü bilgiler elde edilmektedir.

Kıbrıs'a sürgüne gönderilen devlet görevlilerinin burada çok uzun yıllar değil sadece birkaç yıl kaldığı görülmektedir. Cezaların bu şekilde kısa süreliğine verilmesi hem Kıbrıs Adası'nın sürgün yeri olarak ağır koşullu bir bölge olması hem de sürgündeki amacın ceza ile kişilerin hayatlarının ellerinden alınması değil, onların ıslah edilerek ders alması amacını taşıdığı içindir. Zaten Kıbrıs'a sürülen devlet görevlilerinin önemli bir kısmı çeşitli nedenlerle de olsa bir süre sonra affedilmişlerdir. 


\section{KAYNAKC A}

Acehan, A. (2008). “Osmanlı Devleti'nin Sürgün Politikası ve Sürgün Yerleri”. Uluslararası Sosyal Araştırmalar Dergisi, 1/5, 12-29.

Akgündüz A. (1999). "Kanunnâmelerde Ceza Hukuku Hükümleri ve Şer'i Tahlili”. İslâm̂̂ Araştırmalar Dergisi, 12/1, 1-16.

Arslan, H. (2001). 16. Yüzyll Osmanlı Toplumunda Yönetim, Nüfus, İskan, Göç ve Sürgün. İstanbul: Kaknüs Yayınları.

Atlay, D. (1999). “Kıbrıs Türkleri'nin Kökeni Olan Türk Kabileleri ve Kıbrıs'ın Türkleştirilmesi Çalışmalarından Bir Kesit”. İkinci Uluslararası Kıbrıs Araştırmaları Kongresi (24-27 Kasım 1998, II, 455-474. Gazimağusa: Doğu Akdeniz Üniversitesi Kıbrıs Araştırmaları Merkezi Yayınları.

Avagyan, A. (2004). Osmanl Imparatorluğu ve Kemalist Türkiye'nin Devlet-iktidar Sisteminde Çerkesler. Çev. Ludmilla Denisenko. İstanbul: Belge Yayınları.

Babuş, F. (2006). Osmanlı'dan Günümüze Etnik-Sosyal Politikalar Çerçevesinde Göç ve İskan Siyaseti ve Uygulamaları. İstanbul: Ozan Yayınları.

Barkan, Ö. L. (1950). "Osmanlı İmparatorluğunda Bir İskân ve Kolonizasyon Metodu Olarak Sürgünler". Istanbul Üniversitesi İktisat Fakültesi Mecmuası, 11, 524-569.

Barkan, Ö. L. (2002). “Osmanlı İmparatorluğu’nda Kolonizatör Türk Dervişleri”. Türkler, 9, 133-153. Ankara: Yeni Türkiye Yayınları.

Buzpınar, Ş. T. (2002). "II. Abdülhamid Döneminde Filistin'e Yahudi Göçü Meselesi (1878-1908)". Türkler, 13, 78-86. Ankara: Yeni Türkiye Yayınları.

Cöhçe, S. (2000). "İçel Sancağı Ermenak Kazasından Kıbrıs’a Göçürülen Aileler”. Üçüncü Uluslararası Kıbrıs Araştırmaları Kongresi (13-17 Kasım 2000), I, 223-243. Gazimağusa: Doğu Akdeniz Üniversitesi Kıbrıs Araştırmaları Merkezi Yayınları.

Daşçığlu, K. (2007). Osmanlı'da Sürgün. İstanbul: Yeditepe Yayınları.

Dündar, R. (1999). "Kıbrıs'ın Fethi ve İskânı". Osmanll, 4, 632-648. Ankara: Yeni Türkiye Yayınları.

Erdoğru, M. A. (1993). "Kıbrıs'ın Türkler Tarafından Fethi ve İlk İskân Teşebbüsü (1570-1571)". Klbrls'in Dünü-Bugünü Uluslararasl Sempozyumu (28 Ekim-2 Kasım 1991), 45-56. Ankara: K.K.T.C. Doğu Akdeniz Üniversitesi ve T.C. Yüzüncü Yıl Üniversitesi Yayınları.

Erdönmez, C. (2007). "Kıbrıs Tarihi Ders Kitaplarında Osmanlı Devrinde Kıbrıs'a Yapılan Sürgünlerle İlgili Bazı Tespitler". Süleyman Demirel Üniversitesi Fen Edebiyat Fakültesi Sosyal Bilimler Dergisi, $15,65-90$.

Gerçel, A. (1999). "Kıbrıs Tarihinde Göçler". İkinci Uluslararası Kıbrıs Araştırmaları Kongresi (24-27 Kasım 1998, II, 485-495. Gazimağusa: Doğu Akdeniz Üniversitesi Kıbrıs Araştırmaları Merkezi Yayınları.

Gürsoy, C. (1971). "Coğrafya Bakımından Kıbrıs ve Türkiye”. Milletlerarası Birinci Kıbrıs Tetkikleri Kongresi (14-19 Nisan 1969), 41-48. Ankara: Türk Kültürünü Araştırma Enstitüsü Yayınları.

Halaçoğlu, Y. (2006). XVIII. Yüzyılda Osmanlı İmparatorluğu'nun İskân Siyaseti ve Aşiretlerin Yerleştirilmesi. Ankara: TTK. Yayınları.

Halaçoğlu, Y. (2001). Osmanlı Döneminde Kıbrıs'ta İskân Politikası. Dünden Bugüne Kıbrıs Meselesi, 39-46. Yay. Haz. Ali Ahmetbeyoğlu, \& Erhan Afyoncu. İstanbul: Tarih ve Tabiat Vakfı Yayınları.

İpek, N. (2006). Imparatorluktan Ulus Devlete Göçler. Trabzon: Serander Yayınları.

Karaca, B. (1999). "XVI. Asırda Teke Yöresinden Kıbrıs'a Yapılan Sürgünler”. Osmanl,, 4, 649-652. Ankara: Yeni Türkiye Yayınları.

Köksal, O. (2006). "Osmanlı Hukukunda Bir Ceza Olarak Sürgün ve İki Osmanlı Sultanının Sürgünle İlgili Hatt-1 Hümayunları". OTAM, 19, 283-341. Ankara: Ankara Üniversitesi Basımevi.

Manisalı, E. (2003). Dünden Bugüne Kıbrls. İstanbul: Gündoğan Yayınları.

Yıldırım, H. O., \& Atik, V. (2010). Osmanlı İdaresinde Kıbrıs. Ankara: T.C. Başbakanlık Devlet Arşivleri Genel Müdürlüğü Osmanlı Arşivi Daire Başkanlığı Yayınları.

Özkul, A. E. (2005). Kıbrıs'ın Sosyo-Ekonomik Tarihi (1726-1750). İstanbul: İletişim Yayınları. 
Pakalın, M. Z. (1983). Osmanlı Tarih Deyimleri ve Terimleri Sözlüğ̈̈, III. İstanbul: Milli Eğitim Bakanlığı Yayınları.

Yılmaz, M. (1999). "XIX. Yüzyılda Osmanlı Devleti'nin Muhaciri İskân Politikası”. Osmanl, 4, 587-602. Ankara: Yeni Türkiye Yayınları.

\section{Başbakanlık Osmanlı Arşivi Belgeleri (BOA)}

BOA., Sadaret mühimme kalemi evrakı (A.MKT.MHM): 251/86; 330/80

BOA., Sadaret nezaret ve devair evrakı (A.MKT.NZD): 334/86

BOA., Sadaret mektubî kalemi umum vilayat evrakı (A.MKT.UM): 37/13; 192/72; 214/75; 219/31; 406/91; 571/71

BOA., Cevdet askeriye evrakı (C.AS): 862/36917

BOA., Cevdet dahiliye evrakı (C.DH): 236/11768

BOA., Cevdet eyalet-i mümtaze evrakı (C.MTZ): 14/665

BOA., Cevdet zabtiye evrak1 (C.ZB): 29/1404; 67/3347; 89/4420

BOA., Hatt-1 hümayûn tasnifi evrakı (HAT): 196/ 9788; 266/15417

BOA., İradeler meclis-i vala evrak1 (İ.MVL): 235/8212; 434/19139; 584/26280 